\title{
EDITORIAL
}

José Florencio F. Lapeña, Jr. MA, MD

Department of Otorhinolaryngology College of Medicine, University of the Philippines Manila, Philippines

Department of Otorhinolaryngology Head and Neck Surgery

East Avenue Medical Center, Diliman

Quezon City, Philippines

\section{People Giving Hope in the Time of COVID-19: They Also Serve Who Care and Share}

\author{
That murmur, soon replies, "God doth not need \\ Either man's work or his own gifts; who best \\ Bear his mild yoke, they serve him best. His state \\ Is Kingly. Thousands at his bidding speed \\ And post o'er Land and Ocean without rest: \\ They also serve who only stand and wait."1 \\ 'John Milton, Sonnet 19
}

The COVID-19 Pandemic has brought out most of the best (and some of the worst) in us. Much has been said, shared, even sung about health care workers as frontline heroes. Whether we indeed form the frontline, or man the last line of defense, due credit is being given to all "front-liners" - essential-service workers, drivers and delivery personnel, security guards, the military and police who literally serve in the trenches of this invisible war. Indeed, it is heartening to read the inspiring messages, hear the encouraging words, listen to the uplifting (sometimes funny) music and songs, witness the moving memes and cartoons, watch the refreshing dances and tributes, and receive the healing blessings and prayers on various media and social media platforms. Indeed, we are motivated to continue to work, so that others may safely stay home. Some of us have even been called upon to die, so that others may live.

But so much less is and has been said about those who make our battle possible, who selflessly and silently took it upon themselves to clothe us with personal protective equipment, feed us, transport us, and even shelter us as we engage the unseen enemy. It is these heroes I wish to thank today. I certainly cannot thank them all, but I sincerely hope that those I do mention will represent the many others I cannot.

Early on, my brother Elmer Lapeña and his Team Twilight group of "golfing enthusiasts and friends" ("company owners, executives, managers, engineers, technicians, entrepreneurs, and expats in the electronics, semiconductor, metalworking, automotive, aerospace, and packaging manufacturing industries") responded to the call for better protection for frontliners with door-todoor deliveries of Personal Protective Equipment (PPE) to over 40 hospitals in the National Capitol Region, Rizal, Cavite, Laguna and Batangas including the Philippine General Hospital (PGH). ${ }^{2}$ On a personal note, Elmer and my sister-in-law Annette were closely monitoring our situation, going out of their way to obtain difficult-to-find PPEs for my wife Josie and myself, and our respective Departments of Family and Community Medicine (DFCM) and Otorhinolaryngology (ORL) at the PGH.

For her part, our very dear friend Gigi Bautista Rapadas organized Project \#HelpCovid19Warriors(HCW), to "go where the virus goes" and "help where help is needed and requested," harnessing donations from 'family, friends, and friends of friends" to procure PPE (as well as disinfectants, even canned goods) that were distributed "from Metro Manila to the provinces: Tuguegarao, Bataan, Bulacan, La Union, Nueva Vizcaya, Cavite," moving from hospitals and health centers to correctional institutes. ${ }^{3}$ It is because of them that our PGH Department of ORL obtained very expensive but essential respirator hoods for added protection from 


\section{EDITORIAL}

aerosolized virus when conducting airway procedures, in addition to head-to-foot PPEs for use of the PGH DFCM in attending to PGH staff at the UP Health Service.

Meanwhile, without fanfare, our dear friends Popot and Agnes (also my DLSU '79 classmate) Lorenzana provided cooked meals for 1,000 persons daily. Working with on-the-ground social workers and with the 2KK Tulong sa Kapwa Kapatid Foundation, their Feeding Program "A thousand meals for poor communities" reached Payatas, Talayan, Pinyahan, Smokey Mountain, Maisan, Bagong Silang, Old Balara, Tatalon, Sta. Teresita, Sampaloc, and Sta. Ana, among more than 50 other communities. They generously responded to my wife's request to provide meals for her community patients of the Canossa Health Center in Tondo. They have also provided meals for hospital staff of Amang Rodriguez Memorial Medical Center, the Medical City Hospital, Veterans Memorial Medical Center, Dr. Jose Fabella Memorial Hospital, Dr. Jose Rodriquez Memorial Hospital, Quezon City General Hospital, the San Lazaro Hospital, Valenzuela City Emergency Hospital and Lung Center of the Philippines. They continue this service which to date has provided for more than 32,000 meals, with corporate partners and private individuals joining the effort. ${ }^{4}$

Other De La Salle University (DLSU) College '79 batchmates who wish to remain anonymous obtained board approval of their endorsement to channel all the social development funds of their Maritime Multipurpose Cooperative for the next 3 years to the Philippine General Hospital. Adding their personal funds (and those solicited by their daughter and nephew), they took on the daunting task of sourcing and providing Powered Air Purifying Respirators (PAPRs) for our use. Another DLSU batchmate has been distributing PPEs to various hospitals including PGH through their family corporation, Nobleland Ventures, Inc. Even their high school batch '75 of Saint Jude Catholic School has donated boxes and boxes of PPEs to the PGH and other hospitals. Other DLSU '79 classmates Bel and Bong Consing and Timmy, Joy (and Tita Linda) Bautista have personally donated PPEs and funds for our COVID-19 operations, while classmate Fritz de Lange even sent over sweet mangoes for us to enjoy with our fellow frontliners.

Generous donations also poured in from La Salle Greenhills (LSGH) High School '76 friends Cris Ibarra, Norman Uy, Class 4E, and

\footnotetext{
REFERENCES

1. Milton J. Sonnet 19: When I consider how my light is spent. Chicago: The Poetry Foundation 2020 [cited 2020 May 12] Available from: https://www.poetryfoundation.org/poems/44750/ sonnet-19-when-i-consider-how-my-light-is-spent

2. Lapeña EBF. Team Twilight Bayanihan Na Fight COVID19 Philippines. [Internet] 2020 Mar 28 [cited 2020 May 8]. Available from: https://youtu.be/fLu2TYCZWs4

3. Rapadas MAB. \#HelpCovid19Warriors (HCW) Project Update \#10. [Internet] 2020 May 3 [cited 2020 May 8]. Available from: https://m.facebook.com/story.php?story_fbid=102071135217923 94\&id $=1712078668$

4. Lorenzana AAB. A thousand meals for poor communities. 2KK Tulong sa Kapwa Kapatid Foundation. [Internet] [cited 2020 May 11]. Available from: Bit.ly/2KKonLZD

5. Lapeña-Concepcion RAV. "May it Be" by Enya, Arranged by Rey Casey Concepcion. Violin Rosa Lapeña Concepcion, Viola - Rey Casey Concepcion. 2020 April 11 [cited 2020 May 14] Available from: https://www.facebook.com/532526836/posts/10156869813371837/?d=n
}

batchmates Tito and Pepper who wish to remain anonymous, as well as Menchit Borbon and her St. Theresa's College Quezon City (STCQC) Batch '76 - Section 1 classmates. We even received overseas support from my LSGH 4B classmate Bingo Pantaleon from Yangon; my mom Libby, brother Bernie and Lilli, and friend Soyanto from Singapore; and sister Sabine from Germany. And how can we forget the regular frozen food deliveries of Jollibee chicken drumsticks and home-made Bulgogi and Tapa from our dear friends Ed and Aning Go?

Perhaps the most touching gifts of all came from my eldest and youngest daughters Melay and Jica, who lovingly prepared and delivered much-appreciated meals to us, and middle child Ro-an, who with our son-in-law Reycay serenaded us with beautiful music that was appreciated by no less than Vice President Leni Robredo and featured by the Philippine Philharmonic Orchestra. ${ }^{5}$ Their musical fundraising campaign started with another haunting piece featuring my sister Nina and brother-in-law Kiko. ${ }^{6}$ As if that were not enough, Ro-an bakes Happy Wolf Choco Chip cookies to raise funds for our ongoing COVID-19 operations at PGH, while Melay and Jica keep asking us what we want to eat next. Because they themselves do not have much, their gifts are most precious, as they exemplify the proverbial widow who had the least, yet "put in everything she had."7

These are but a few examples of those known personally to me- my family and friends. And there are many more. In the same way, every other doctor and front liner will have their own stories to tell, of friends, family even mere acquaintances who have come out of the shadows to help, to care, to share in whatever way they can, in fighting this battle with us. Let this be their tribute as well.

Those of us who serve in the Philippine General Hospital have been called People Giving Hope., ${ }^{8,9}$ I believe that we do give hope because others give us hope in turn. I would like to think that the inscription in the PGH lobby "They Also Serve Who Care and Share" honors these others in a special way who go over and beyond the call of duty. With apologies to John Milton, our heroes go way over and beyond "they also serve who only stand and wait."

Maraming Salamat po sa inyong lahat.

and https://www.facebook.com/philippinephilharmonic/videos/vb.485712851781922/2382 $96100613076 /$ type $=2 \&$ theater

6. Lapeña-Concepcion RAV. "Nearer My God to Thee" Violin 1 - Corinna Lapeña Llorin, Violin 2 - Rosa Lapeña Concepcion, Viola - Rey Casey Concepcion, Cello - Francisco Llorin. 2020 April 5 [cited 2020 May 14]. Available from https://www.facebook.com/532526836/ posts/10156850534476837/?d=n

7. Mark 12:42-44. The Bible with the Apocryphal/Deuterocanonical Books. New Revised Standard Version. Copyright $\odot 1989$, Division of Christian Education of the National Council of the Churches of Christ in the United States of America.

8. Legaspi GD. To the People Giving Hope (PGH). [Letter on the Internet] 2020 March 26 [cited 2020 May 14]. Available from: https://www.facebook.com/philippinegeneralhospitalofficial/ photos/a.2554926417871915/3107212802643271/?type=3\&theater

9. Philippine General Hospital. People Giving Hope - PGH [Personal Blog] 2020 April [cited 2020 May 14]. Available from: https://www.facebook.com/PeopleGivingHope/ 